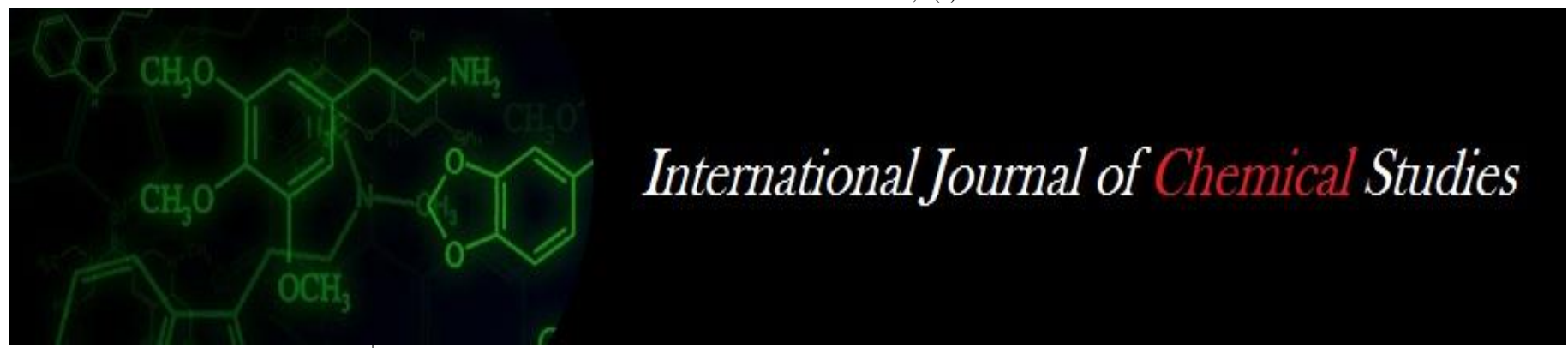

P-ISSN: 2349-8528

E-ISSN: 2321-4902

www.chemijournal.com

IJCS 2021; 9(1): 1945-1947

(C) 2021 IJCS

Received: 24-10-2020

Accepted: 30-12-2020

Karraja Kathyayani

M.Sc. Ag. 4th Semester Student,

Department of Agronomy,

SHUATS, Prayagraj, Uttar

Pradesh, India

Rajesh Singh

Assistant Professor, Department

of Agronomy, SHUATS,

Prayagraj, Uttar Pradesh, India

Punnam Chhetri

Ph.D., Student, Department of Agronomy, SHUATS, Prayagraj,

Uttar Pradesh, India
Corresponding Author: KarrajaKathyayani

M.Sc. Ag. 4th Semester Student Department of Agronomy,

SHUATS, Prayagraj, Uttar

Pradesh, India

\section{Effect of levels of boron and molybdenum on economics of Blackgram (Vigna mungo L.) cultivation}

\author{
Karraja Kathyayani, Rajesh Singh and Punnam Chhetri
}

DOI: $\underline{\text { https://doi.org/10.22271/chemi.2021.v9.i1aa.11507 }}$

\section{Abstract}

A field experiment was conducted to determine the effect of levels of Boron and Molybdenum on Economics of Blackgram cultivation. The experiment was laid out in Randomized Block Design, with 12 treatments, each replicated thrice, in the kharif 2019 with the different levels of Boron $(0.1 \%, 0.2 \%, 0.3 \%$ of Borax solution) and Molybdenum(0.5,1.0,1.5 Mo $\mathrm{Kg} / \mathrm{ha}$ ) respectively at Crop Research Farm, Department of Agronomy, SHUATS, Prayagraj (U.P). Application of Boron and Molybdenum significantly influenced the economics of Blackgram. Addition of $0.3 \%$ solution of Borax $+1.5 \mathrm{~kg} \mathrm{Mo} / \mathrm{ha}$ recorded the maximum Gross realization (Rs. 56100) was observed with the treatment T9 (R.D.F $+0.3 \%$ Solution of Borax $+1.5 \mathrm{~kg} \mathrm{ha}^{-1}$ of Molybdenum) Maximum net returns (Rs27783) were also recorded with the same treatment. The highest benefit cost ratio was recorded as $(1.73: 1)$ with above said treatment.

Keywords: Blackgram, kharif, boron, molybdenum, growth, yield attributes

\section{Introduction}

Blackgram belongs to family Leguminoseae. Blackgram (Vigna mungo L.) is the important pulse crop of India cultivated over a wide range of agro - climatic zones of the country. This crop is grown in Kharif and Rabi seasons, however, maximum area is under Kharif cultivation where intercropping with sorghum, pearl millet, maize, cotton, castor, pigeonpea is very popular.

Blackgram also occupies about more than 4.50 million ha area in the country producing 2.83 million tonnes. The major blackgram growing states of the country are Maharashtra, Uttar Pradesh, Andhara Pradesh, Madhya Pradesh and Tamil Nadu.

The total area under the crop has increased progressively from 1.84 million ha in 1965 - 66 to 4.50 million ha in 2016 - 17. Similarly, the production has increased from 0.55 million tonnes to 2.83 million tonnes during the same period. In the state of Maharashtra this crop is grown on 0.48 million ha area with the production of 0.18 million tonnes and the average productivity of the state is $365 \mathrm{~kg} \mathrm{ha}^{-1}$. Blackgram is the important pulse crop of Vidarbha region of Maharashtra covering 0.10 million ha with the production of 0.04 million tones registering the productivity of $387 \mathrm{~kg} \mathrm{ha}^{-1}$ (AICRP)

Micronutrients are essential elements that are used by plants in small quantities to orchestrate a range of physiological functions. Application of micronutrients increase the yield and quality of agricultural products.

Boron (B) is one of the most important trace elements, which is essential for normal life cycle of the plants. It influences the absorption of nitrogen, phosphorus, potassium and its deficiency affects the equilibrium of these macronutrients. Boron plays a key role in sugar translocation, nodulation, nitrogen fixation, protein synthesis, sucrose synthesis, cell wall composition, membrane stability, $\mathrm{K}+$ transport, viability of pollen, pollen germination and pollen tube growth and pollination and seed set. Boron deficiency commonly results in empty pollen grains, poor pollen vitality and a reduced number of flowers per plant besides stunted root growth as shown in the soybean and canola.

Studies on molybdenum application to crop revealed that, cereals and legumes showed a higher response compared to other crops. It is important for good foliage growth, nitrogen fixation and nitrogen assimilation as a constituent of nitrogenous and nitrate reductive and 
inhibiting acid phosphates. It retranslocate freely from roots, stem and leaves. Khan and Prakash (2014) ${ }^{[7]}$ application of molybdenum up to $1.0 \mathrm{~kg} \mathrm{ha}^{-1}$ significantly increased growth characters, number and dry weight of root nodules, seed and Stover yield, nutrient uptake, gross and net returns and benefit: cost ratio.

\section{Materials and Methods}

The experiment was carried out during Kharif season of 2019 at Crop Research Farm, Department of Agronomy, Naini Agricultural Institute, SHUATS, Prayagraj (U.P). The soil of the experimental plot was sandy loam in texture, nearly neutral in soil reaction ( $\mathrm{pH} 7.2$ ), low in organic carbon $(0.58 \%)$, medium in available $\mathrm{N}(238 \mathrm{Kg} / \mathrm{ha})$, high in available $\mathrm{P}(32.10 \mathrm{Kg} / \mathrm{ha})$ and low in available $\mathrm{K}(189 \mathrm{Kg} / \mathrm{ha})$. The treatment consisted of T1:R.D.F+0.1\% solution of borax at $15,30,45 \mathrm{DAS}+0.5 \mathrm{~kg} \mathrm{ha}^{-1}$ of Molybdenum,T2: R.D.F + $0.1 \%$ solution of Borax $+1 \mathrm{~kg}$ ha- 1 of Molybdenum, T3: R.D.F $+0.1 \%$ solution of Borax, $1.5 \mathrm{~kg} \mathrm{ha}^{-1}$ of Molybdenum, T4:R.D.F $+0.2 \%$ solution of Borax $+0.5 \mathrm{~kg} \mathrm{ha}^{-1}$ of Molybdenum, T5: R.D.F $+0.2 \%$ solution of Borax $+1.0 \mathrm{~kg}$ $\mathrm{ha}^{-1}$ of Molybdenum, T6:R.D.F $+0.2 \%$ solution of Borax + $1.5 \mathrm{~kg} \mathrm{ha}^{-1}$ of Molybdenum, T7:R.D.F $+0.3 \%$ solution of Borax $+0.5 \mathrm{~kg} \mathrm{ha}^{-1}$ of Molybdenum, T8:R.D.F $+0.3 \%$ solution of Borax $+1.0 \mathrm{~kg} \mathrm{ha}^{-1}$ of Molybdenum and T9:R.D.F $+0.3 \%$ solution of Borax $+1.5 \mathrm{~kg} \mathrm{ha}^{-1}$ of Molybdenum. There are 9 treatments each replicated thrice. The experiment was laid out in Randomized Block Design. It was sown on 25th July 2019 with seed rate $\mathrm{Kg} / \mathrm{ha}$ at spacing $30 \mathrm{~cm} \times 10 \mathrm{~cm}$.
Recommended doses of nitrogen, phosphorus and potassium were applied.

\section{Results and Discussions}

Economics of all treatments were calculated according to expenditure incurred from the land preparation till harvesting of the crop. Gross return, net return, cost of cultivation were calculated and are presented in the Tables no.1.

The maximum Gross realization (Rs. 56100) was observed with the treatment $\mathrm{T}_{9}$ (R.D.F $+0.3 \%$ Solution of Borax +1.5 $\mathrm{kg} \mathrm{ha-1}$ of Molybdenum) Maximum net returns (Rs27783) were also recorded with the same treatment. The highest benefit cost ratio was recorded as $(1: 1.73)$ with above said treatment Khan et al. (2014) ${ }^{[7]}$ revealed that the application of molybdenum up to $1.0 \mathrm{~kg} \mathrm{ha}{ }^{-1}$ significantly increased the number and dry weight of nodules plant - 1 , uptake of nitrogen, zinc, molybdenum in urdbean and increases gross and monetary return and benefit: cost ratio. Karpagam and Rajesh (2014) ${ }^{[6]}$ reported that with increasing levels of Mo, the pod yield, seed yield and haulm yield also increases and the highest benefit : cost ratio of 2.79 was recorded with soil application of Mo @ $1000 \mathrm{~g} \mathrm{ha}^{-1}$ as sodium molybdate. Rathi et al. (2009) found that application rhizobium along S @ 4kg $\mathrm{ha}^{-1}$ B @ $0.6 \mathrm{kgha}^{-1}$ and Mo @ $0.1 \mathrm{~kg} \mathrm{ha}^{-1}$ significantly increased the yield and economics of Blacgram. Quddus et al. (2011) observed that the combined application $\mathrm{Zn} 1.5 \mathrm{~kg}$ ha ${ }^{1}$ B $1.0 \mathrm{kgha}^{-1}$ produced significantly higher yield $(3058 \mathrm{~kg}$ ha ${ }^{1}$ ) and economics of Mungbean over single application of both nutrients.

Table 1: Effect of levels of boron and molybdenum on economics of blackgram

\begin{tabular}{|c|c|c|c|c|c|c|c|c|}
\hline \multirow{2}{*}{ Treatment combinations } & \multirow{2}{*}{$\begin{array}{c}\text { Cost of } \\
\text { Cultivation }\end{array}$} & \multicolumn{2}{|c|}{ Yield } & \multicolumn{2}{|c|}{ Sale rate } & \multirow[t]{2}{*}{\begin{tabular}{|c|}
$\begin{array}{c}\text { Gross return } \\
\left(\text { ha }^{-1}\right)\end{array}$ \\
\end{tabular}} & \multirow[t]{2}{*}{\begin{tabular}{|c|}
$\begin{array}{c}\text { Net Return } \\
\left(\text { ha }^{-1}\right)\end{array}$ \\
\end{tabular}} & \multirow[t]{2}{*}{$\begin{array}{l}\text { B:C } \\
\text { ratio } \\
\end{array}$} \\
\hline & & $\begin{array}{l}\text { Grain } \\
\text { (kg/ha) }\end{array}$ & $\begin{array}{l}\text { Stover } \\
\text { (kg/ha) }\end{array}$ & \begin{tabular}{|l|}
$\begin{array}{l}\text { Grains } \\
\text { (kg/ha) }\end{array}$ \\
\end{tabular} & $\begin{array}{l}\text { Stover } \\
\text { (kg/ha) }\end{array}$ & & & \\
\hline $\mathrm{T}_{1}$ R.D.F $+0.1 \%$ of Borax $+0.5 \mathrm{~kg} / \mathrm{ha}$ of Molybdenum & 36,982 & 651 & 1441 & 39060 & 7205 & 46265 & 9284 & $1.2: 1$ \\
\hline $\mathrm{T}_{2}-$ R.D.F+ $0.1 \%$ of Borax $+1.0 \mathrm{~kg} / \mathrm{ha}$ & 37,682 & 764 & 1668 & 45840 & 8340 & 54180 & 16498 & $1.45: 1$ \\
\hline $\mathrm{T}_{3}-$ R.D.F $+0.1 \%$ of Borax $+1.5 \mathrm{~kg} / \mathrm{ha}$ of Molybdenum & 37,982 & 847 & 1799 & 50820 & 8995 & 59815 & 21833 & $1.15: 1$ \\
\hline $\mathrm{T}_{4}$-R.D.F+0.2\% of Borax+0.5kg/ha of Molybdenum & 37,382 & 908 & 1576 & 54480 & 7880 & 62360 & 24978 & $1.60: 1$ \\
\hline $\mathrm{T}_{5}$ R.D.F+0.2\% of Borax $+1.0 \mathrm{~kg} / \mathrm{ha}$ of Molybdenum & 37,682 & 858 & 1793 & 51480 & 8965 & 60445 & 22765 & $1.16: 1$ \\
\hline T6-R.D.F+0.2\% of Borax+1.5kg/ha of Molybdenum & 37,782 & 908 & 1876 & 54480 & 9380 & 63860 & 26478 & $1.70: 1$ \\
\hline $\mathrm{T}_{7}$-R.D.F+0.3\% of Borax+0.5kg/ha of Molybdenum & 37,182 & 802 & 1723 & 48120 & 8615 & 56735 & 19555 & $1.52: 1$ \\
\hline $\mathrm{T}_{8}$-R.D.F+0.3\% of Borax+1.0kg/ha of Molybdenum & 37,482 & 883 & 1821 & 52980 & 9105 & 62085 & 24603 & $1.65: 1$ \\
\hline $\mathrm{T}_{9}-$ R.D.F+0.3\% of Borax $+1.5 \mathrm{~kg} / \mathrm{ha}$ of Molybdenum & 37,847 & 935 & 1906 & 56100 & 9530 & 65630 & 27783 & $1.73: 1$ \\
\hline
\end{tabular}

\section{Conclusion}

It may be concluded that the treatment T9 (R.D.F $+0.3 \%$ Solution of Borax +1.5 kgha- 1 of Molybdenum) was found best for obtaining the maximum grain yield (19.06 q/ha) and the highest benefit cost ratio was recorded in the treatment T9 (R.D.F $+0.3 \%$ Solution of Borax $+1.5 \mathrm{~kg}$ ha-1 of Molybdenum) which was (1.73:1).

\section{References}

1. Alam MS, Islam MF. Effect of zinc and boron on seed yield and yield contributing traits of mungbean in acidic soil. Journal of Bioscience and Agriculture Research 2016;11(02):941-946.

2. Alam MS, Ali KJ, Hoque A. Yield and Yield Component of Chickpea as Affected by Boron Application. Journal of Experimental Agriculture International 2017;15(2):1-9.

3. Gautam S, Pandey SN, Srivastava MN. Effect of Ni on seedling growth, physiological attributes in black gram (Vigna mungo) in leaves. International Journal of Current Research 2014;6(9):8673-8676.
4. Awomi TA, Singh AK, Kumar M, Borodoloi LJ. Effect of Phosphorus, Molybdenum and Cobalt Nutrition on Yield and Quality of Mungbean (Vigna radiata L.) in Acidic Soil of Northeast India. Indian Journal of Hill Farming 2012;25(2):22-26.

5. Devi KV, Singh MS, Singh SB, Singh KK. Influence of Sulphur and Boron Fertilization on Yield, Quality, Nutrient Uptake and Economics of Soybean (Glycine max) under Upland Conditions. Journal of Agricultural Science 2012;4(4):1-10.

6. Karpagam J, Rajesh N. Molybdenum Application for Enhancing Growth, Yield and Soil Health on Green Gram (Vigna radiata L.). American-Eurasian Journal of Agricultural \& Environmental Sciences 2014;14(12):1378-1381.

7. Khan K, Prakash V. Effect of rhizobial inoculation on growth, yield, nutrient and economics of summer urdbean (Vigna mungo L. Hepper) in relation to zinc and molybdenum. International Journal of Advanced 
Research in Chemistry and Chemical Engineering 2014;1(1):1-10.

8. Khan N, Tariq M, Ullah K, Muhammad D, Khan I, Rahatullah K, Ahmed N et al. The Effect of Molybdenum and Iron on Nodulation, Nitrogen and Yield of Chickpea Genotypes (Cicer arietinum L). Journal of Agriculture and Veterinary Science 2014;7(1):63-79.

9. Malik K, Kumar S, Arya KPS. Effect of zinc, molybdenum and urea on growth and yield of mungbean (Vigna radiata L. Wilczek). Advance research journal of crop improvement 2015;6(1):59-65.

10. Rahman MM, Bhuiyan MMH, Sutradhar GN, Rahman CMM, Paul AK. Effect of phosphorus, molybdenum and rhizobium inoculation on yield and yield attributes of mungbean. International journal of sustainable crop production 2008;3(6):26-33.

11. Rathi BK. Effect of rhizobium, sulphur and micronutrients on the nodulation in black gram. Research front, special issue 2016;(1):209-212.

12. Tahir M, Sher A, Majeed MA. Effect of Molybdenum on yield and quality of blackgram (Vigna mungo (L.) Hepper). Pakistan journal of life and social sciences 2014;12(2):101-105.

13. Valenciano JB, Boto JA, Marcelo V. Response of chickpea (Cicer arietinum L.) yield to zinc, boron and molybdenum application under pot conditions. Spanish Journal of Agricultural Research 2010;8(3):797-807.

14. Wasaya A, Shabir MS, Hussain M, Ansar M, Aziz A, Hassan W et al. Foliar application of Zinc and Boron improved the productivity and net returns of maize grown under rainfed conditions of Pothwar plateau. Journal of soil science and plant nutrirtion 2017;17(1):1-10. 